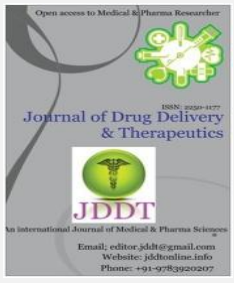

Open $\bigcirc$ Access

Research Article

\title{
Spectrophotometric analysis of tablets of nalidixic acid using melted niacinamide as solvent
}

\author{
${ }^{1}$ R.K. Maheshwari, ${ }^{1}$ Apeksha Apte*, ${ }^{1}$ Mitali Jain, ${ }^{2}$ Om Prakash Agrawal \\ ${ }^{1}$ Department of Pharmacy, Shri G.S Institute of Technology and Science, Indore, India- 452003 \\ ${ }^{2}$ School of Pharmacy, Madhyanchal Professional University, Ratibad, Bhopal-462044.
}

\begin{abstract}
In the current attempt of research, novel method for spectrophotometric estimation of nalidixic acid in tablets using melted niacinamide as solvent was developed. The main objective behind research is to show "SOLIDS ALSO POSSESS SOLUBILIZING POWER". The current study deals with novel spectrophotometric analytical technique for quantitative estimation of nalidixic acid in tablets using melted niacinamide as solvent. According to the theory proposed by Maheshwari, each \& every substance possesses solubilising power; substance may be a gas, solid or liquid. Niacinamide imbibes large solubilizing power to nalidixic acid and having approximate solubility more than $80 \mathrm{mg}$ per gm of melted niacinamide $\left(135^{\circ} \mathrm{C}\right)$ whereas aqueous solubility of nalidixic acid is $0.21 \mathrm{mg} / \mathrm{ml}$ at room temperature. Calibration curve of nalidixic acid was plotted by recording the absorbances of standard solutions of drug. The absorbances were observed at $330 \mathrm{~nm}$ against respective reagent blanks. The percentage label claims were found very close to 100 (100.93 \pm 1.303 and 99.08 \pm 1.764$)$ indicating accuracy of the proposed method. Percentage recoveries estimated by the proposed method are close to $100(99.91 \pm 1.303$ and $101.74 \pm 1.663)$ with significant low values of percentage deviation and standard error. Thus, it may be concluded that proposed method is simple, safe and precise and excludes use of toxic organic solvents.
\end{abstract}

Keywords: Mixed Solvency, Solubilizing Power, Spectrophotometric Analysis, Niacinamide, Nalidixic Acid.

Article Info: Received 15 Jan 2019; $\quad$ Review Completed 31 Jan 2019; Accepted 02 Feb 2019; Available online 15 Feb 2019

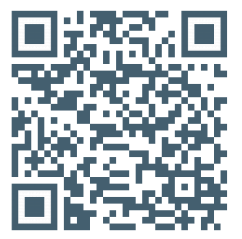

Cite this article as:

Apeksha Apte, Department of Pharmacy, Shri G.S Institute of Technology and Science, Indore, India - 452003, Journal of Drug Delivery and Therapeutics. 2019; 9(1-s):206-208 DOI: http://dx.doi.org/10.22270/jddt.v9i1-s.2323

\section{*Address for Correspondence:}

niacinamide as solvent

Maheshwari RK, Apte A, Jain M, Agrawal OP, Spectrophotometric analysis of tablets of nalidixic acid using melted

\section{INTRODUCTION}

The mixed solvency concept can serve as a milestone for solubility enhancement and therefore deserves an urgent attention of the scientific community to assess its efficiency and applicability. According to Maheshwari, each and every substance present on earth possesses solubilizing power be it a solid, liquid or gas. Some substances are good solvent for some and at the same time bad solvent for others ${ }^{1-10}$.

Commonly used organic solvents for spectrophotometric analysis of water insoluble drugs include methanol, ethanol, chloroform, benzene, dichloromethane, dimethyl formamide, actonitrile, ethyl acetate, toluene, carbon tetrachloride, acetone, hexane etc. The main drawbacks of organic solvents include high cost, toxicity and pollution. Organic solvents have innumerous adverse effects caused by single exposure like dermatitis, headache, drowsiness, nausea, eye irritation and long term exposure causes serious effects such as neurological disorders, chronic renal failure, liver damage, necrosis, mutagenesis disorder. They should be replaced by other eco-friendly alternative sources. The present investigation is an attempt to show that solids can also be ISSN: 2250-1177 wisely used to act as solvent precluding the use of organic solvents. In a separate study, author has attempted soxhelation using phenol as solvent. The vapours of boiling phenol got condensed in extraction chamber to effect the extraction of active constituents from powder of crude drugs. The main objective of the present study is to demonstrate the solvent action of solids. Solid excipients can nicely be employed as solubilizers in the development of pharmaceutical dosage forms in solution form of poorly soluble drugs (mixed solvency concept) 11-20.

In the present research, melted Niacinamide (at $135^{\circ} \mathrm{C}$ ) was employed for dissolution of nalidixic acid without using any organic solvents (therefore eco-friendly method).

\section{MATERIALS AND METHOD}

Nalidixic acid API was generous gift from M/S Alkem Laboratories Ltd., Mumbai. Nalidixic acid tablets were procured from the local market. All other chemicals were of analytical grade. The instrument used was Shimadzu UVVisible spectrophotometer (model UV-160A) with $1 \mathrm{~cm}$ matched silica cells. 


\section{Experimental Methods}

\section{Solubility Studies}

The solubility of nalidixic acid at room temperature was found to be $0.21 \mathrm{mg} / \mathrm{ml}$. Using approximate method of solubility determination, it was found that more than $80 \mathrm{mg}$ nalidixic acid was dissolved by one gram of melted niacinamide (at $135^{\circ} \mathrm{C}$ ).

\section{Calibration Curve}

$10 \mathrm{gm}$ niacinamide was taken in a $500 \mathrm{ml}$ volumetric flask and it was heated carefully on heating mantle. As soon as niacinamide was melted, $50 \mathrm{mg}$ of standard sample of nalidixic acid was added and the flask was shaken to dissolve the drug. Intermittent heating and shaking was done for complete dissolution of drug. Then, the volume was made up to $500 \mathrm{ml}$ with distilled water. This was the stock solution of drug $(100 \mu \mathrm{g} / \mathrm{ml})$. By appropriate dilution of this stock solution with distilled water, standard solutions of the drug $(10,20,30,40,50 \mu \mathrm{g} / \mathrm{ml})$ were prepared and their absorbances were noted at $330 \mathrm{~nm}$ against the respective reagent blanks and using these values, the calibration curve was obtained.

\section{Proposed Method}

20 tablets of nalidixic acid, formulation I were weighed and crushed to get a fine powder. Ten gms of niacinamide was kept in a $500 \mathrm{ml}$ volumetric flask and the flask was carefully heated on heating mantle to melt the niacinamide. After complete melting of niacinamide, tablet powder equivalent to $50 \mathrm{mg}$ of drug was transferred to the flask and the flask was shaken for 10 minutes with intermittent heating and shaking. Then, $400 \mathrm{ml}$ of hot $\left(90^{\circ} \mathrm{C}\right)$ distilled water was carefully (little at a time) added to the flask and the flask was shaken for about 5 minutes. Then, the flask was allowed to cool to attain room temperature and the volume was made up to mark with distilled water. After filtration through Whatman filter paper no.41, $5 \mathrm{ml}$ filtrate was diluted to $50 \mathrm{ml}$ with distilled water and the absorbance was noted at $330 \mathrm{~nm}$ against reagent blank. Using calibration curve the drug content was computed. Similar treatment was done for formulation II. All analyses were performed thrice.

\section{Recovery Studies}

Recovery studies taking $15 \mathrm{mg}$ and $30 \mathrm{mg}$ of pure drug as spiked drug together with pre-analysed tablet powder (equivalent to $50 \mathrm{mg}$ ) were performed using the same proposed method.

\section{RESULTS AND DISCUSSION}

The aqueous solubility of nalidixic acid at room temperature was $0.21 \mathrm{mg} / \mathrm{ml}$ whereas the solubility of nalidixic acid in melted niacinamide was found to be more than $80 \mathrm{mg}$ per gram of melted niacinamide at $135^{\circ} \mathrm{C}$. It is evident from Table 1 that the percent drug estimated in formulation I and II were $100.93 \pm 1.303$ and $99.08 \pm 1.764$, respectively. The values are very close to 100 , indicating accuracy and precision of the proposed method. Further, Table 2 shows that the range of percent recoveries varied from $99.91 \pm$ 1.142 to $101.74 \pm 1.663$ which are again very close to 100.0 , indicating the accuracy of the proposed method. Proposed analytical technique is supported significantly by small values of statistical parameters viz. standard deviation, percent coefficient of variation and standard error (Table 2).

Table 1: Analysis of Commercial Tablets of Nalidixic acid with Statistical Evaluation $(n=3)$

\begin{tabular}{|l|l|l|l|l|}
\hline $\begin{array}{l}\text { Tablet } \\
\text { Formulation }\end{array}$ & $\begin{array}{l}\text { Label Claim Per Tablet } \\
\text { (mg) }\end{array}$ & $\begin{array}{l}\text { \% Label Claim Estimated } \\
\text { (mean+sd) }\end{array}$ & $\begin{array}{l}\text { \% Coefficient of } \\
\text { Variation }\end{array}$ & $\begin{array}{l}\text { Standard } \\
\text { Error }\end{array}$ \\
\hline I & 500 & $100.93 \pm 1.303$ & 1.291 & 0.752 \\
\hline II & 500 & $99.08 \pm 1.764$ & 1.780 & 1.018 \\
\hline
\end{tabular}

Table 2: Results of Recovery Studies with Statistical Evaluation $(n=3)$

\begin{tabular}{|l|l|l|l|l|l|}
\hline $\begin{array}{l}\text { Tablet } \\
\text { formulation }\end{array}$ & $\begin{array}{l}\text { Drug present in } \\
\text { preanalyzed tablet } \\
\text { powder taken (mg) }\end{array}$ & $\begin{array}{l}\text { Pure drug added } \\
\text { (spiked)(mg) }\end{array}$ & $\begin{array}{l}\text { \% Recovery } \\
\text { estimated (mean } \pm \\
\text { sd) }\end{array}$ & $\begin{array}{l}\text { \% Coefficient } \\
\text { of variation }\end{array}$ & $\begin{array}{l}\text { Standard } \\
\text { error }\end{array}$ \\
\hline I & 50 & 15 & $99.91 \pm 1.142$ & 1.143 & 0.659 \\
\hline I & 50 & 30 & $100.67 \pm 1.064$ & 1.057 & 0.614 \\
\hline II & 50 & 15 & $101.74 \pm 1.663$ & 1.635 & 0.906 \\
\hline II & 50 & 30 & $99.92 \pm 1.605$ & 1.606 & 0.927 \\
\hline
\end{tabular}

\section{CONCLUSION}

The mixed solvency concept can be successfully employed in analytical estimation of various drugs. A large number of poorly water-soluble drugs having absorption maxima above $300 \mathrm{~nm}$ can be tried for estimation by this method. Such solvents (niacinamide) can be tried in place of costlier and toxic organic solvents. 


\section{REFERENCES}

1. Maheshwari RK. "Mixed-solvency approach"- Boon for solubilization of poorly soluble drugs. Asian Journal of Pharmaceutics 2010; Jan-March: 60-63.

2. Maheshwari RK. Solubilization of ibuprofen by mixed solvency approach. The Indian Pharmacist 2009; 8(87):81-84.

3. Maheshwari RK. "Mixed- solvency" - A novel concept for solubilization of poorly water-soluble drugs. Delving J. Tech. Eng. Sci. 2009; 1(1):39-43.

4. Rajesh Kumar Maheshwari, "Solid as solvent", Novel spectrophotometric analysis of satranidazole tablets using phenol as solvent. The Indian Pharmacist 2014; XII: 37-40.

5. Maheshwari RK. Potentiation of solvent character by mixed solvency concept: A novel concept of solubilization. Journal of Pharmacy Research 2010; 3(2):411-413.

6. Maheshwari RK, Shilpkar R. Formulation development and evaluation of injection of poorly soluble drug using mixed solvency concept. International Journal of Pharma and Biosciences 2012; 3(I):179-189.

7. Maheshwari RK, Upadhyay N, Jain J, Patani M, Mathuria KC. New spectrophotometric estimation of naproxen tablet formulation employing mixed solvency concept (at $331 \mathrm{~nm}$ ). International Journal of Pharmacy and Technology 2011; 3(4):3618-3623.

8. Soni LK, Solanki SS, Maheshwari RK. Solubilization of poorly water soluble drug using mixed solvency approach for aqueous injection. British Journal of Pharmaceutical Research 2014; 4(5):549-568

9. Maheshwari Y, Mishra DK, Mahajan SC, Maheshwari P, Maheshwari RK, Jain J. Novel pharmaceutical application of mixed solvency in the formulation development of syrups (liquid oral solutions) of poorly water-soluble drugs. International Journal of Pharmacy 2013; 3(4):753-758.

10. Maheshwari RK, Rajagopalan R. Formulation and evaluation of tinidazole syrup made by mixed-solvency concept. Der Pharmacia Lettre 2011; 3(6):266-271.

11. Bhawsar N, Maheshwari RK, Ansari A, Saktawat Y. New spectrophotometric estimation of gatifloxacin in the tablets using mixed solvency approach. International Journal of Pharmaceutical Science 2011; 2(2):270-274.
12. Maheshwari RK, Karawande VU, Application of novel concept of mixed solvency in the design and development of floating microspheres of furosemide. International journal of Pharmacy and Pharmaceutical Sciences 2013; 15:167-195.

13. Maheshwari RK, Upadhyay N, Jain J, Patani M, Pandey R. New spectrophotometric analysis of gatifloxacin tablets utilizing mixed solvency concept (at $288 \mathrm{~nm}$ ). Der Pharmacia Lettre 2012; 4(1):1-4.

14. Agrawal A, Maheshwari RK. Formulation development and evaluation of in situ nasal gel of poorly water soluble drug using mixed solvency concept. Asian Journal of Pharmaceutics 2011; 5(3):131-140.

15. Sreegiriprasad B, Gupta VRM, Devanna N, Ramadevi M, Vishnuvarethan rao G. Mixed Solvency Concept: A promising tool to enhance solubility of poorly soluble drug aceclofenac. International Journal of Pharmaceutical Chemical and Biological Sciences 2012; 3:338-342.

16. Chandna C, Maheshwari RK. Mixed solvency concept in reducing surfactant concentration of self emulsifying drug delivery systems of candesartan cilexetil using D-optimal mixture design. Asian Journal of Pharmaceutics 2013; AprilJune: 83-91.

17. Vijayranga G, Deveswaran R, Bharath S, Basavraj BV, Madhavan V. Development of an analytical method for spectrophotometric estimation of ketoprofen using mixed solvency approach. International Journal of Pharmaceutical Sciences and Research 2012; 4:1053-1056.

18. Prashant B, Rawat S, Mahajan YY, Galgatte UC, Maheshwari RK. Formulation development and evaluation of aqueous injection of poorly soluble drug made by novel application of mixed solvency concept. International Journal of Drug Delivery 2013; 2:152-166.

19. Maheshwari RK, Gupta S, Gharia A, Garg SK, Shilpkar R. Simple eco-friendly spectrophotometric estimation of tinidazole tablets by application of mixed-solvency technique. Bulletin of Pharmaceutical Research 2011; 1(1):22-25.

20. Maheshwari RK, Rajagopalan R. Formulation and evaluation of paracetamol syrup made by mixed-solvency concept. Der Pharmacia Lettre 2012; 4(1):170-174. 